\title{
Intention of Entrepreneurship in the Young Generation of Agriculture (Case of Diponegoro University Faculty of Animal Husbandry and Agriculture)
}

\author{
Della Arny Novera \\ Faculty of Economic and Business \\ Diponegoro University \\ Indonesia
}

\author{
Lili Marliyah \\ Faculty of Teacher Training and Education \\ Ivet University \\ Indonesia
}

\author{
Purbayu Budi Santosa \\ Faculty of Economic and Business \\ Diponegoro University \\ Indonesia
}

\begin{abstract}
The entrepreneurial intentions of the young generation in the agricultural sector are decreasing from year to year. Based on this, it is important to question the characteristics of agricultural student entrepreneurial intentions. Many university graduates are unemployed but on the other hand there are still agricultural sectors that can be potential for these graduates to be developed and become one of their career choices going forward. This research provides support for the application of TPB (Theory of Plan Behavior) and the concept of entrepreneurial intentions to understand the emergence of complex economic behaviors such as entrepreneurship before the emergence of observable actions. The purpose of this study was to determine the intentions of agricultural entrepreneurs and the facts that influence them. Questionnaire filling by 100 students of the Faculty of Animal Husbandry and Agriculture of the University of Diponegoro was carried out using incidental sampling techniques and descriptive statistical analysis methods. The results showed that the interests of UNDIP's animal husbandry and agriculture faculty were determined significantly by attitude, while subjective norms and behavioral control had no effect on entrepreneurial intentions. As many as $66 \%$ of students are interested in entrepreneurship in the agricultural sector.
\end{abstract}

Keywords:- Agropreneurship; intention; theory of plan behavior.

\section{INTRODUCTION}

The agricultural sector has the potential to support economic growth, especially in developing countries in ASEAN, this can be seen from the contribution of agriculture in the aggregate through Indonesia's Gross Domestic Product (GDP). Until now, the majority of Indonesia's population still chooses the farming business as their main source of income. The agricultural sector in 2018 is able to absorb labor force in Indonesia by $30.46 \%$ (BPS, 2019), the figure is far greater than other sectors.

Potential agriculture/agribusiness sectors have not yet been fully developed as the driving force for national economic development. The analysis can be seen from the problem of economic development by showing low competitiveness. Based on data from the World Economic Forum (2019) in the report of the Global Competitiveness Index (CGI), Indonesia ranks 50th out of 141 countries surveyed in ASEAN, which means it has decreased by 5 (five) levels compared to similar surveys a year earlier. competitiveness with Singapore, Malaysia and Thailand. The competitiveness of the economy in Indonesia is an indication that is used as a reflection of the minimal number of competent entrepreneurs, plus the minimal number of entrepreneurs in the agribusiness sector. Therefore, Indonesia needs entrepreneur farmers with a sufficient amount and competence in their fields.

Entrepreneur Farmer is a farmer who is entrepreneurial to get business opportunities through his farming activities, so that entrepreneurial activities on a rural scale are important (Pichardo, González, Hernández and McElwee, 2012; Erik, 2006; Henderson, 2006; McElwee, 2006) Therefore, the prosperity of an agrarian-style country has a relationship with the quality and quantity of entrepreneur farmer. It is very important that an entrepreneur farmer has an interest in entrepreneurship, and the notion of an entrepreneurial interest is an interest in the activities of running a business.

The intention of entrepreneurs in this study was stated by Ajzen (1991) in the theory of planned behavior, where the intention is related to a high tendency to do entrepreneurship in the agricultural sector. It is very necessary to study related to entrepreneurial intentions in the younger generation in the agricultural sector which from year to year is declining. Based on this, it is important to question the characteristics of agricultural student 
entrepreneurial intentions and analyze the factors that influence them. The existence of low intentions on young entrepreneurs in the agricultural sector pushed the Indonesian Ministry of Agriculture to launch the 2016 Agriculture Young Entrepreneur Growth Program. This program aims to reduce educated unemployment of college graduates and foster regeneration of Human Resources in the agricultural sector closely related to increasing entrepreneurial intentions in the agricultural sector, so it is important to know entrepreneurial intentions with attitudes toward behavior, subjective norms, and perceived behavioral control.

Some studies from the results of research on the same topic stated by Riana (2018) said that attitude towards behavior, subjective norm, and perceived behavioral control have been proven to influence student intentions in entrepreneurship. The research is not in line with the research of Arisandi (2016); Ibrahim and Afifi (2018); Ridha and Wahyu (2017); Shiri (2012) which says that the factors that influence entrepreneurial intentions in the agricultural sector are subject to external or external factors, while the attitude toward the behavior and perceived behavioral control factors do not affect the entrepreneurial intentions in the agricultural sector. Trisnawati's research (2011) found that subjective norms and attitudes had a positive relationship with entrepreneurial intentions. Adebayo and Kavoos (2016); Devi (2015); Mahmoud (2014); Zampetakis, Anagnosti, and Rozakis (2013) which stated that attitude is the strongest factor that influences entrepreneurial intentions.

\section{RESEARCH METHOD}

This type of research is an ex post facto research with descriptive quantitative research methods. This study analyzes the influence of attitudes, subjective norms, and behavioral control on the entrepreneurial intentions of students majoring in agribusiness at the Faculty of Agriculture and Animal Husbandry, Diponegoro University, Semarang. The population in this study were active students of the Faculty of Agriculture and Animal Husbandry totaling 15050 (Bureau of Student Administration UNDIP, 2019) and the study sample was determined by incidental sampling technique.

Based on the Slovin formula, the sample size can be determined at 100 with sample criteria including: (1) agricultural students who have taken entrepreneurship courses and (2) agricultural students who have passed the initial semester (towards entrepreneurial mental maturity). Data collection methods used in this study were observation, documentation and questionnaire. Descriptive statistical analysis methods are used for data analysis by describing the data samples in conditions according to reality, so that the regression equation of this study: Intention $=\alpha+\beta 1$ Attitude $+\beta 2$ Subjective Norms $+\beta 3$ Behavioral Control.

The dependent variable in this study is entrepreneurial intentions in agricultural students. Entrepreneurial intentions are a component of someone who tends to show a willingness to act / act certain. Indicators on entrepreneurial intention variables include: planning to establish a business within 5 (five) years (starting from now), confidence in establishing a business within 5 (five) years (starting from now), confidence in establishing an agricultural business within a period of 5 ( five) years (starting from now), high entrepreneurial intentions, and high entrepreneurial intentions in the agricultural sector.

Attitude towards behavior (attitude) is a belief about the consequences of behavior or behavioral beliefs. Indicators to measure attitude towards behavior (attitude) are the consequences of beliefs and disciplinary evaluations, the consequences of beliefs and evaluations that dare to take risks, the beliefs of consequences and evaluations of honesty, the beliefs of consequences and confidence evaluation, consequence beliefs and creative evaluation, consequence beliefs and innovative evaluations, consequence beliefs and independence evaluations, consequence beliefs and leadership evaluations, consequent beliefs and diligent evaluations, consequence beliefs and evaluation of target planning.

Subjective norms are one's perceptions of the desires of those around them that become significant others related to what they do or do not. Researchers modify subjective norm indicators, including beliefs and compliant encouragement of team expectations, beliefs and motivations to comply with people's expectations parents, beliefs and encouragement to obey family expectations, beliefs and encouragement to obey the expectations of lecturers, and beliefs and encouragement to obey the expectations of friends.

Perceived behavioral control is a view that depends on one's beliefs related to resources that encourage or inhibit the behavior. Thus, indicators of perceived behavioral control variables include: easy belief and control power in access to financial institutions, easy belief and control power in overcoming fatigue / boredom, easy belief and control power in overcoming the complexity of entrepreneurship, and easy belief and control power in fulfilling agreements .

\section{RESULT AND DISCUSSION}

Based on the research results, it is known that the student population in the Faculty of Animal Husbandry and Agriculture of UNDIP is 15050 students, the number of students is then analyzed based on sample criteria, the results obtained are 100 students who meet the criteria of the research sample. In the majority of respondents from the department of agrotechnology by $33 \%$, the second largest respondent majoring in animal husbandry by $30 \%$, then agribusiness by $19 \%$, food technology by $18 \%$ students.

Research respondents entered into the even school year which consisted of semester II, IV, VI, and VIII. Semester $\mathrm{VI}$ is the semester that has the largest proportion of $46 \%$ compared to other semesters, followed by the largest proportion by semester IV of $38 \%$. This condition is indicated that semester VI has a maturity level of interest in 
farming. It is said that if the productive age of young people aged 15-35 years, so also the respondents in this study consisted of youth with a dominating age of 20 years by $42 \%$, while the age of 19 years was $28 \%$ and age by $21 \%$ by $20 \%$.

Respondents in this study were dominated by female sex, where the proportion of women was $52 \%$ and the proportion of men was $48 \%$. These conditions indicate that women's interest in entrepreneurship in agriculture is higher than men. Respondents in this study were mostly dominated by the work of entrepreneurs fathers, private employees and civil servants, with each proportion of $28 \%, 20 \%$, and $18 \%$. While the work as a farmer is only $15 \%$. This shows that most of the Faculty of Animal Husbandry and Agriculture students come from well-off families, and have experience in entrepreneurship. On the other hand the occupation of mothers is dominated by not working by $40 \%$ and entrepreneurship by $22 \%$. It also shows that mothers are more focused on taking care of the household and economic conditions are supported by fathers. While entrepreneurial mothers also indicate being a motivator for students to have an entrepreneurial interest. Agriculture is divided into 2 fields where most students are more interested in on-farm fields by $62 \%$ compared to off farm $38 \%$. This condition is indicated that students are brave enough to take the risk of farming in the field.

The results of the research in the field show the distribution of scores categorized in the high, medium and low categories. The low category is the category where the respondents are very unsure that they are interested in becoming an agripreneur with a score range below 1.67 in the low category. The category is identifying that respondents are less sure that they are interested in becoming an agripreneur with a score range of 1.67 to 3.33 . The last category is the high category which states that the respondents are very confident that they are interested in an agripreneur with a score range above 3.33. All aspects of entrepreneurial intentions fall into the high category, where none is indicated to have low entrepreneurial interest. Respondents' answers spread by an average of 3.66 to 4.06 , where the highest average value is 4.06 in the aspect of high entrepreneurial intentions and the lowest average value is 3.58 in the aspect of belief in establishing an agricultural business.

The results of descriptive analysis on the entrepreneurial intention variable showed the majority of respondents answered the high category in the aspect of planning to set up a 5 -year business period by $74 \%$. This indicates that respondents have a high interest in entrepreneurship by showing the existence of a 5-year business plan. Making plans and targets in business needs to be done to motivate and execute the business undertaken. The majority of respondents answered the belief aspect of establishing a business for a period of 5 years, into the high category with a percentage of $64 \%$. This shows that the respondents were very confident to become agripreneur. Meanwhile, the aspect of confidence in establishing an agricultural business within a period of 5 years is included in the high category with a percentage of $51 \%$, the moderate category (in doubt) by $33 \%$ and the rest in the low category by $16 \%$. This proves that they believe in establishing a business in agriculture, but there are still doubts about this agricultural business.

Descriptive analysis results show that attitude variables in all aspects are in the high category with an average percentage above $72 \%-97 \%$. Meanwhile, the only innovative aspect in the high category is $58 \%$, the moderate category is $36 \%$. None of the aspects are included in the low category. Respondents' answers spread by an average of 3.76 to 4.51 . The highest average value is the honesty aspect and the lowest average value is the innovative aspect. This proves that respondents are confident with the consequences and evaluations of the ten attitudes in establishing a business in agriculture, but there are still doubts about the start of this farming business.

Whereas the subjective norms of variables in all aspects are in the high category with a percentage of $81 \%$ $93 \%$ and none of the aspects is included in the low category. Respondents' answers spread by an average of 3.84 to 4.48 . The highest average value is the aspect of belief and motivation to comply with the expectations of lecturers and the lowest average value is the aspect of belief and motivation to comply with family expectations. This shows that the respondents are very confident and have high motivation to become agripreneur based on social pressure to act to start a business .

Aspects of the behavioral control variable are also included in the high category with a percentage of $87 \%$ in the aspects of easy confidence and strength of control on access to financial institutions as well as aspects of easy belief and strength of control in overcoming fatigue / boredom by $94 \%$. While easy confidence and strength of control in overcoming the complexity of entrepreneurship is high but not as significant as the previous 2 aspects at $49 \%$. Aspects of easy confidence and power of control in fulfilling agreements in the medium category are $45 \%$ and $45 \%$ high and none of the aspects fall into the low category. Respondents' answers spread by an average of 3.27 to 4.46 . The highest average value is the aspect of easy belief and control power in overcoming fatigue / boredom and the lowest average value is the aspect of easy belief and control strength in fulfilling the agreement. This shows that the respondent is very confident and has a high control power to become an agripreneur based on aspects and there is little doubt about the aspect of fulfilling the agreement.

Based on the ANNOVA table, the significance value obtained $=0,000<0.05$ or $5 \%$, then this study shows that attitudes, subjective norms, and behavioral control have a significant effect on entrepreneurial intentions. Attitude variable obtained t count 4.682 with a significance of 0.000 , then because the significance value $<0.05$ means that attitude has a significant positive effect on entrepreneurial intentions. While subjective norms and behavioral control variables obtained t count respectively 0.186 and 1.018 with a significance of 0.853 and 0.311 . Because the significance 
value> 0.05 means that subjective norms and behavioral control do not significantly influence entrepreneurial intentions. Attitude regression, subjective norms and behavioral control over entrepreneurial intentions in agricultural students.
INTENTION $=3,314+0,304$ ATTITUDE $+0,023$ SUNJECTIVE NORM $+0,114$ BEHAVIORAL CONTROL $+0,7$

\begin{tabular}{|l|r|r|r|r|r|}
\hline \multirow{2}{*}{ Model } & \multicolumn{2}{|c|}{$\begin{array}{c}\text { Unstandardized } \\
\text { Coefficients }\end{array}$} & $\begin{array}{c}\text { Standardized } \\
\text { Coefficients }\end{array}$ & \multirow{2}{*}{$\mathrm{t}$} & \multirow{2}{*}{ Sig. } \\
\cline { 2 - 4 } & \multicolumn{1}{|c|}{$\mathrm{B}$} & \multicolumn{1}{c|}{ Std. Error } & \multicolumn{1}{c|}{ Beta } & & \\
\hline (Constant) & 3.314 & 3.781 & & .876 & .383 \\
\hline ATTITUDE & .304 & .065 & .538 & 4.682 & .000 \\
\hline SUBJECTIVE NORM & .023 & .123 & .023 & .186 & .853 \\
\hline BEHAVIORAL CONTROL & .114 & .112 & .096 & 1.018 & .311 \\
\hline
\end{tabular}

a. Dependent Variable: INTENTION

Table 1:- Test Results t

Source: Primary data, processed in 2020.

The partial determination coefficient ( $\mathrm{r} 2$ ) is used to find out the amount of contribution made by each exogenous variable (attitude, subjective norms, and behavioral control) to the entrepreneurial intentions partially. The magnitude of the coefficient of partial determination ( $\mathrm{r} 2$ ) can be seen from the coefficient column of the partial correlation column, then the value is squared and converted into a percentage form.

\begin{tabular}{|c|c|c|c|c|c|c|c|c|}
\hline \multirow{2}{*}{ Model } & \multicolumn{2}{|c|}{$\begin{array}{l}\text { Unstandardized } \\
\text { Coefficients }\end{array}$} & \multirow{2}{*}{$\begin{array}{c}\begin{array}{c}\text { Standardized } \\
\text { Coefficients }\end{array} \\
\text { Beta }\end{array}$} & \multirow{2}{*}{$\mathrm{t}$} & \multirow{2}{*}{ Sig. } & \multicolumn{3}{|c|}{ Correlations } \\
\hline & $B$ & $\begin{array}{l}\text { Std. } \\
\text { Error }\end{array}$ & & & & $\begin{array}{l}\text { Zero- } \\
\text { order }\end{array}$ & Partial & Part \\
\hline (Constant) & 3.314 & 3.781 & & .876 & .383 & & & \\
\hline ATTITUDE & .304 & .065 & .538 & 4.682 & .000 & .645 & .435 & .351 \\
\hline SUBJECTIVE NORM & .023 & .123 & .023 & .186 & .853 & .524 & .019 & .014 \\
\hline BEHAVIORAL CONTROL & .114 & .112 & .096 & 1.018 & .311 & .416 & .104 & .076 \\
\hline
\end{tabular}

a. Dependent Variable: INTENTION

Table 2:- Results of Partial Determination Coefficients (r2)

Source: Primary data, processed in 2020

Based on table 2, it can be interpreted that the magnitude of the influence of attitudes on entrepreneurial intentions can be seen at $\mathrm{r} 2$ value of $(0.435) 2 \mathrm{X} 100 \%=$ $18.9 \%$. This shows that the attitude variable partially affects entrepreneurial intentions by $18.9 \%$, assuming that the other exogenous variables are considered permanent. The magnitude of the effect of subjective norms on entrepreneurial intentions can be seen in the $\mathrm{r} 2$ value of (0.019) $2 \times 100 \%=0.04 \%$. This shows that partially the subjective norm variable influences the entrepreneurial intention variable by $0.04 \%$, assuming that the other exogenous variables are considered fixed. The magnitude of the effect of behavioral control on entrepreneurial intentions can be seen in the $\mathrm{r} 2$ value of $(0.104) 2 \times 100 \%=1.1 \%$. This shows that partially the behavioral control variable influences the entrepreneurial intention variable by $1.1 \%$, assuming that the other exogenous variables are considered fixed.

\section{The positive effect of attitude on student entrepreneurial intentions}

The low interest of young generation in agriculture is the background of this research to find out how the entrepreneurial intentions of agribusiness students are. Through entrepreneurship in the agricultural sector (entrepreneur farmer) is expected to be able to move its business in the scope of the agricultural base, so that it has the potential to become an opportunity in its contribution to reduce unemployment and become a driving force for national economic development.

The phenomenon of increasingly aging farmers (aging farmers) becomes a supporting problem for the need for entrepreneur farmers, it is due to a decrease in labor interest in agriculture, especially the younger generation (Susilowati, 2016a). These concerns encourage the determination of determinants of entrepreneurial intentions based on the theory of planned behavior, which are attitudes, subjective norms, and behavioral control. One of them, attitude towards behavior (attitude) is the extent to which someone assesses something that is beneficial for himself and compares it with things that are not profitable (Novanda, 2017). This research formulates that there is an influence of attitude towards behavior (attitude) on entrepreneurial intentions. This is in line with Trisnawati (2012); Nowinski (2019) states that attitude influences entrepreneurial intentions. On the other hand, there are different evidences that are not in line to encourage researchers to further investigate that entrepreneurial attitudes do not have a positive influence on entrepreneurial intentions (Ibrahim, 2018; Novanda, 2017). 
$>$ The positive influence of subjective norms on student entrepreneurial intentions

The agricultural sector must still be improved by requiring innovative development in which agricultural human resources become an influential contribution to sustainable development. The phenomenon of aging farmers and the lack of young agricultural workers is a global problem. Setiawan (2012) said that the progress of agricultural and / or agribusiness civilization actually happened not only because of the life of a minority of creative farmers, but occurred because of the life of a minority of creative farming community actors. Historically, agricultural progress has taken place because agriculture or agribusiness has been used as basic capital by all parties including scientists, artists, writers, designers, architects, doctors, economists, technologists, sociologists, and others.

One of them is the change in the agriculture sector that is related to subjective norm. Subjective norms are social pressures in acting or inaction (Novanda, 2017). This study formulates the influence of subjective norm factors on entrepreneurial intentions. This is also consistent with the statement that subjective norms and self-perceptions have a positive influence on entrepreneurial intentions (Ibrahim, 2018; Novanda, 2017). Likewise, research by Trisnawati (2012) states that subjective norms and attitudes have a positive relationship with entrepreneurial intentions.

\section{$>$ The positive effect of behavioral control on} entrepreneurial intentions

The importance of the role of higher education is due to the lack of entrepreneurs who are competent with the quality of science and adequate quantity in agriculture. Therefore, young entrepreneurial farmers are needed to develop creativity and ideas in providing the latest innovations, so that these young entrepreneurs are able to add value to agricultural products. Growing the entrepreneurial spirit is very necessary behavior control early to control how the behavior acts in accordance with the desired goals.

Behavioral control is the ease or difficulty in carrying out certain actions that are assumed (Novanda, 2017). This study formulates the influence of attitude towards behavior towards entrepreneurial intentions. This is based on the statement that states that entrepreneurial self efficacy (perceived behavior control) is most effective for strengthening entrepreneurial intentions among universities (Nowinski, 2019). However Novanda's (2017) research is not in line with that statement, that perceived behavioral control has no effect.

\section{CONCLUSSION}

Descriptively the majority of respondents are of the view that attitude variables in the high category will be indicators of consequence beliefs and honesty evaluations, consequent beliefs and diligent evaluations, consequence and evaluation beliefs taking risks, consequence beliefs and target planning evaluations, and consequence beliefs and creative evaluations. Subjective norm variables as a whole are in the high category with the highest indicators of belief and motivation to comply with lecturer expectations. Behavioral control variables on indicators of easy belief and strength of control on access to financial institutions and easy belief and strength of control in overcoming fatigue / boredom in the high category. While indicators of easy confidence and strength of control in overcoming the complexity of entrepreneurship and easy confidence and strength of control in fulfilling agreements in the medium category. The results showed that the interests of UNDIP animal husbandry and agriculture faculty were determined by attitude, while subjective norms and behavioral control had no effect on entrepreneurial intentions. The growth of entrepreneurial spirit is very necessary in order to foster entrepreneurial intentions in the younger generation, especially in the early years through the planting of strong and successful entrepreneurial attitudes in agriculture.

\section{ACKNOWLEDGMENT}

The authors are obliged to the Prof. Dr. Purbayu Budi Santosa, M.S, Dr. Lili Marliyah, M.P, Magister of Economic and Development Studies, Faculty of Animal Husbandry and Agriculture of University Diponegoro, Semarang, Indonesia for providing necessary approval to work and also facilities to accomplish investigation.

\section{REFERENCES}

[1]. Adebayo, G. S., dan Kavoos, M, "The present attitude of African youth towards entrepreneurship", International Journal of Small Business and Entrepreneurship Research, vol 4(1), pp. 21-38, 2016.

[2]. Ajzen, I, "The theory of planned behavior", Organizational behavior and human decision processes, vol 50(2), pp. 179-211, 1991.

[3]. Arisandi, "Intensi Berwirausaha Mahasiswa Pascasarjana Institut Pertanian Bogor Pada Bidang Agribisnis (Studi Kasus Pada Mahasiswa Program Magister Sps-Ipb)", (Pascasarjana), Institut Pertanian Bogor, Bogor, 2016.

[4]. BPS, "Struktur PDB Menurut Lapangan Usaha 2019", from Badan Pusat Statistika, 2019.

[5]. Devi, M, "A study on the influencing factors for a literate youth to take up agricultural entrepreneurship", International Journal of Management and Commerce Innovations, vol 3(1), pp. 692-700, 2015.

[6]. Díaz-Pichardo, R., Cantú-González, C., LópezHernández, P., dan McElwee, G., "From farmers to entrepreneurs: The importance of collaborative behaviour", The Journal of Entrepreneurship, vol 21(1), pp. 91-116, 2012.

[7]. Enayati, F., "Human Capital as a Factor of Economic Growth", Review of Economic Sciences, vol 12, pp. 101-114, 2007.

[8]. Engle, R. L., Dimitriadi, N., Gavidia, J. V., Schlaegel, C., Delanoe, S., Alvarado, I., Wolff, B., "Entrepreneurial intent: A twelve-country evaluation of Ajzen's model of planned behavior", International 
Journal of Entrepreneurial Behavior \& Research, vol 16(1), pp. 35-57, 2010.

[9]. Erik R, D., "Center For Rural Entrepreneurship, Understanding The Environment For Entrepreneurship", 2006 , Retrieved from http://www.entreworks.net/Download/SupportingRura IEntrepreneurship.pdf.

[10]. Henderson, J., "Understanding rural entrepreneurship at the county level: Data challenges", Federal Reserve Bank of Kansas City, Omaha, 2006.

[11]. Hmieleski, K., dan Lerner, DA., "The dark triad and nascent entrepreneurship: An examination of unproductive versus productive entrepreneurial motives", Journal of Small Business Management, vol 54(S1), pp. 7-32, 2016.

[12]. Ibrahim, S. B., danAfifi, O., "Determinants of entrepreneurial intentions using Theory of Planned Behavior", Journal of Economic and Management Sciences, vol 19(2), 2018.

[13]. Novanda, R. R., "Intensi Wirausaha Sektor Pertanian Pada Generasi Muda (Studi Kasus Program Penumbuhan Wirausaha Muda Pertanian)", (Pascasarjana), Institut Pertanian Bogor, Bogor, 2017.

[14]. Nowiński, W., dan Haddoud, M. Y., "The role of inspiring role models in enhancing entrepreneurial intention", Journal of Business Research, vol 96, pp. 183-193, 2019.

[15]. Riana, W. C., "Intensi Berwirausaha Mahasiswa Pertanian Indonesia dan Malaysia pada Sektor Pertanian”, (Skripsi), Institut Pertanian Bogor, Bogor, 2018.

[16]. Ridha, R. N., danWahyu, B. P., "Entrepreneurship intention in agricultural sector of young generation in Indonesia", Asia pacific journal of innovation and entrepreneurship, vol 11(1), pp. 76-89, 2017.

[17]. Setiawan, I., "Agribisnis kreatif: pilar wirausaha masa depan, kekuatan dunia baru menuju kemakmuran hijau", Penebar Swadaya Grup, 2012.

[18]. Shane, S., "A general theory of entrepreneurship. Northampton", MA: Edward Elgar Publishing, 2003.

[19]. Shiri, N., Mohammadi, D., and Hosseini, S. M., "Entrepreneurial intention of agricultural students: effects of role model, social support, social norms and perceived desirability", Archives of Applied Science Research, vol 4(2), pp. 892-897, 2012.

[20]. Trisnawati, E., "Pengaruh Pendidikan Kewirausahaan Terhadap Intensi Berwirausaha Mahasiswa Institut Pertanian Bogor Melalui Pendekatan Theory of Planned Behavior", (Skripsi), Institut Pertanian Bogor, Bogor, 2011.

[21]. WEF, W. E. F., "GCI Global Compeititiveness Index", (Publication no. http://reports.weforum.org/global-competitivenessindex-2017-2018/competitiveness-rankings/ ), Retrieved 12 Desember 2019.
[22]. Zampetakis, L. A., Anagnosti, A., dan Rozakis, S., "Understanding entrepreneurial intentions of students in agriculture and related sciences", Paper presented at the Poster session presented at the meeting of the EEAE 2014 Congress" Agri-Food and Rural Innovations for Healthier Societies," Ljubljana, Slovenia, 2013. 